\title{
COVID-19 in Children: Clinical Characteristics and Follow-Up Study
}

\author{
Pei-sen Ruan ${ }^{1} \cdot$ Hui-qing Xu ${ }^{1}$ • Jun-hua $W^{1}{ }^{1}$ Q Qi-fa Song ${ }^{2} \cdot$ Hai-yan Qiu ${ }^{1}$ \\ Accepted: 28 August 2020 / Published online: 3 September 2020 \\ (C) Springer Nature Switzerland AG 2020
}

\begin{abstract}
Since December 2019, the coronavirus disease 2019 (COVID-19) has spread globally. But the clinical symptoms and detailed follow-up of children with COVID-19 infection are lacking. Here, we conducted a retrospective study including children with confirmed COVID-19. We recorded patients' epidemiological, clinical features, and follow-up data after discharging in order to improve the awareness and treatment of children with COVID-19.
\end{abstract}

Keywords Children $\cdot$ COVID-19-infected $\cdot$ Clinical features $\cdot$ Epidemiological $\cdot$ Follow-up

\section{Introduction}

Since December 2019, multiple patients of pneumonia infected with the emergence of severe acute respiratory syndrome coronavirus 2 disease (COVID-19) had been detected in Wuhan city, China [1]. With the spreading of the epidemic, other more patients had also founded in China and other countries [2]. At present, pediatric patients have been reported all over the world, mainly asymptomatic and mild infections. With the progress of the epidemic and the innovation of detection technology, it was not ruled out that pediatric patients were particularly severe, and the number of critically infected children had increased and died. As children were also susceptible to COVID-19 infection and they need more attention. So, analysis of the clinical characteristics, epidemiological characteristics, and follow-up results after discharge of pediatric patients with confirmed COVID-19 in this area was aimed at improving the awareness and treatment of children with COVID-19.

This article is part of the Topical Collection on Covid 19

Hai-yan Qiu

pt1223@126.com

Pei-sen Ruan

pts1223@sina.com

Hui-qing $\mathrm{Xu}$

xuhuiqing413@sina.com

Jun-hua Wu

wudata@163.com

\section{Methods}

We retrospectively analyzed 5 children with COVID-19 admitted to Ningbo Women and Children's Hospital after diagnosed on Feb 4, 2020, to April 6, 2020. Diagnosis and discharge standards were performed according to the content of the "Diagnosis and treatment guidelines for 2019 novel coronavirus pneumonia (Trial Version 7) (In Chinese) [3]." We observed and recorded the patient's epidemiological characteristics, clinical manifestations, laboratory tests, radiography, treatment methods, and transfer return. From the beginning of hospitalization to 4 weeks after discharge, we performed a dynamic tracking including laboratory tests, radiographic inspection, and SARS-CoV-2 RT-PCT in nasopharyngeal and feces swabs. We tested the SARS-CoV-2 of feces swabs and nasopharyngeal swabs every 2 days throughout the process. We conducted a blood laboratory and radiographic 3 times (on the day of discharge, 2 weeks after discharge, and 4 weeks after discharge).

Qi-fa Song

songqf@nbcdc.org.cn

1 Department of Pediatrics, Ningbo Women and Children's Hospital, No.339 Liuting Street, Haishu District, Ningbo City 315000 , Zhejiang Province, China

2 Department of Microbiology, Ningbo Municipal Centre for Disease Control and Prevention, Ningbo 315010, Zhejiang, China 


\section{Results}

\section{Epidemiological Characteristics of Pediatric Patients with COVID-19}

Between Feb 4, 2020, and April 6, 2020, 5 pediatric patients with COVID-19 were reported in Ningbo in China (aged 12133 months; mean age 77.6 [SD 52.3] months). Two (40\%) of 5 patients were female. The household registration of 3 patients was in Zhejiang province, and the other 2 were in Hubei province. All patients had no underlying disease. We found that 5 patients were all family cluster infection (100\%), and there were 3 to 6 confirmed infections in the family. All of the patients contacted with adult patients with novel coronavirus pneumonia (NCP).
Clinical Features of Pediatric Patients with COVID-19

One patient had the symptoms of nasal congestion and runny nose $(20 \%)$, which resolved after 5 days. None had symptoms of fever (ear temperature: $36.3 \sim 37.0{ }^{\circ} \mathrm{C}$ ), shortness of breath (SpO2: 98 100\%), cough, wheezing, dyspnea, headache, chest pain, vomiting, diarrhea, and other manifestations. The clinical classification was acute upper respiratory tract infection in 1 patient (20\%) and asymptomatic infection in 4 patients $(80 \%)$. Typical abnormal laboratory findings were elevated lymphocytes (1 [20\%]), elevated aspartate aminotransferase (1 [20\%]), elevated creatine kinase MB (1 [20\%]), and decreased fibrinogen (2 [40\%]) (Table 1). Mean SARS-
Table 1 Epidemiological and clinical features of pediatric patients with COVID-19

\begin{tabular}{|c|c|c|c|c|c|}
\hline & $\begin{array}{l}\text { Patient } \\
\text { no.1 }\end{array}$ & $\begin{array}{l}\text { Patient } \\
\text { no. } 2\end{array}$ & $\begin{array}{l}\text { Patient } \\
\text { no.3 }\end{array}$ & $\begin{array}{l}\text { Patient } \\
\text { no.4 }\end{array}$ & $\begin{array}{l}\text { Patient } \\
\text { no.5 }\end{array}$ \\
\hline \multicolumn{6}{|l|}{ Epidemiological data } \\
\hline Age(months) & 124 & 133 & 12 & 79 & 40 \\
\hline Gender(male or female) & Male & Male & Female & Female & Male \\
\hline Hometown(Zhejiang Province, China) & $\checkmark$ & $\checkmark$ & $\checkmark$ & $x$ & $x$ \\
\hline Family members with COVID-19 & 3 & 5 & 3 & 6 & 6 \\
\hline \multicolumn{6}{|l|}{ Symptoms } \\
\hline Nasal congestion & $\checkmark$ & $x$ & $x$ & $x$ & $x$ \\
\hline Runny nose & $\checkmark$ & $x$ & $x$ & $x$ & $x$ \\
\hline Pharyngeal congestion & $\checkmark$ & $\checkmark$ & $\checkmark$ & $\checkmark$ & $x$ \\
\hline Sore throat & $\checkmark$ & $\checkmark$ & - & $x$ & $x$ \\
\hline $\begin{array}{l}\text { Other symptoms (fever, cough, dyspnea, } \\
\text { etc.) } \\
\text { Laboratory tests (reference values) }\end{array}$ & $x$ & $x$ & $x$ & $x$ & $x$ \\
\hline $\begin{array}{l}\text { White blood cells }\left(3.5-9.5 \times 10^{9} \text { cells per }\right. \\
\text { L) }\end{array}$ & 7.1 & 8.0 & 9.5 & 5.6 & 3.9 \\
\hline Neutrophil count $\left(1.8-6.3 \times 10^{9}\right.$ cells per L) & 4.8 & 5.0 & 2.0 & 1.6 & 1.2 \\
\hline Lymphocytes $\left(1.1-3.2 \times 10^{9}\right.$ cells per $\left.\mathrm{L}\right)$ & 1.6 & 2.2 & 6.6 & 3.2 & 2.4 \\
\hline Platelet count $\left(125-350 \times 10^{9}\right.$ cells per $\left.\mathrm{L}\right)$ & 365 & 216 & 261 & 198 & 204 \\
\hline C-reactive protein $(<8 \mathrm{mg} / \mathrm{L})$ & 2.67 & 5.88 & 0 & 0.35 & 0.84 \\
\hline Procalcitonin $(<0.5 \mathrm{ng} / \mathrm{mL})$ & $<0.12$ & $<0.12$ & $<0.12$ & $<0.01$ & $<0.01$ \\
\hline Alanine aminotransferase (7-45 U/L) & 36 & 13 & 14 & 10 & 10 \\
\hline Aspartate aminotransferase(13-45 U/L) & 47 & 21 & 39 & 31 & 28 \\
\hline Blood urea nitrogen $(2.7-8.2 \mathrm{mmol} / \mathrm{L})$ & 4.1 & 4.9 & 6.7 & 7.9 & 4.4 \\
\hline Blood creatinine(69-106umol/L) & 29 & 29 & 15 & 22 & 23 \\
\hline Creatine kinase (38-174 U/L) & 57 & 49 & 11 & 148 & 76 \\
\hline Creatine kinase $\mathrm{MB}(<20 \mathrm{U} / \mathrm{L})$ & 8 & 10 & 141 & 16 & 13 \\
\hline Fibrinogen (200-400 mg/dL) & 256 & 304 & 138 & 138 & 204 \\
\hline Prothrombin time $(7.5-13.7 \mathrm{~s})$ & 12.2 & 13.1 & 11.4 & 11.7 & 12.6 \\
\hline $\begin{array}{l}\text { Activated partial thromboplastin time } \\
\quad(21.5-39.5 \mathrm{~s})\end{array}$ & 35.3 & 37.5 & 23.9 & 32.6 & 34 \\
\hline DD-dimer $(\leq 230 \mu \mathrm{g} / \mathrm{L})$ & 47 & 68 & 97 & 54 & 82 \\
\hline \multicolumn{6}{|l|}{ Radiography } \\
\hline Inflammatory changes in the lungs & $x$ & $x$ & $x$ & $x$ & $x$ \\
\hline
\end{tabular}

$\boldsymbol{\checkmark}$, with; $\boldsymbol{X}$, without; - , none cooperate; COVID-19, coronavirus disease 2019 
Table 2 Clinical features of pediatric patients with COVID-19 during 4 weeks follow-up (Supplementary material)

\begin{tabular}{|c|c|c|c|c|c|c|c|c|c|c|c|c|c|c|c|}
\hline \multirow[b]{2}{*}{ Epidemiological data } & \multicolumn{3}{|c|}{ Patient no.1 } & \multicolumn{3}{|c|}{ Patient no.2 } & \multicolumn{3}{|c|}{ Patient no. 3} & \multicolumn{3}{|c|}{ Patient no. 4} & \multicolumn{3}{|c|}{ Patient no. 5} \\
\hline & & & & & & & & & & & & & & & \\
\hline Age (months) & \multicolumn{3}{|l|}{124} & \multicolumn{3}{|l|}{133} & \multicolumn{3}{|l|}{12} & \multicolumn{3}{|l|}{79} & \multicolumn{3}{|l|}{40} \\
\hline Gender (male OR female) & \multicolumn{3}{|c|}{ Male } & \multicolumn{3}{|c|}{ Male } & \multicolumn{3}{|c|}{ Female } & \multicolumn{2}{|c|}{ Female } & & \multicolumn{3}{|c|}{ Male } \\
\hline Observation time after discharge (weeks) & 0 & 2 & 4 & 0 & 2 & 4 & 0 & 2 & 4 & 0 & 2 & 4 & 0 & 2 & 4 \\
\hline Symptoms (fever, cough, dyspnea, etc.) & $x$ & $x$ & $x$ & $x$ & $x$ & $x$ & $x$ & $x$ & $x$ & $x$ & $x$ & $x$ & $x$ & $x$ & $x$ \\
\hline \multicolumn{16}{|l|}{ Laboratory tests (reference values) } \\
\hline White blood cells $\left(3.5-9.5 \times 10^{9}\right.$ cells per $\left.\mathrm{L}\right)$ & 5.3 & 5.4 & 5.1 & 5.1 & 6.3 & 6.9 & 9.0 & 9.7 & 11 & 7.6 & 8.4 & 7.9 & 8.6 & 8.0 & 7.4 \\
\hline Neutrophil count $\left(1.8-6.3 \times 10^{9}\right.$ cells per $\left.\mathrm{L}\right)$ & 2.7 & 2.8 & 2.6 & 2.4 & 3.2 & 3.7 & 1.8 & 2.5 & 3.6 & 3.6 & 3.7 & 3.4 & 1.9 & 3.0 & 3.2 \\
\hline Lymphocytes $\left(1.1-3.2 \times 10^{9}\right.$ cells per $\left.\mathrm{L}\right)$ & 2.1 & 2.2 & 2.0 & 1.8 & 2.3 & 2.2 & 6.5 & 6.4 & 6.7 & 4.1 & 4.2 & 3.9 & 3.4 & 4.3 & 4.1 \\
\hline Hemoglobin $(120-140$ g per L) & 126 & 134 & 128 & 128 & 135 & 135 & 123 & 133 & 135 & 136 & 131 & 133 & 121 & 108 & 112 \\
\hline Platelet count $\left(125-350 \times 10^{9}\right.$ cells per $\left.\mathrm{L}\right)$ & 359 & 375 & 371 & 241 & 278 & 295 & 230 & 279 & 232 & 233 & 266 & 251 & 230 & 248 & 226 \\
\hline C-reactive protein $(<8 \mathrm{mg} / \mathrm{L})$ & 0.5 & 0.6 & 0.5 & 0 & 0 & 0 & 0 & 0 & 0.2 & 0.1 & 0 & 0 & 0 & 0.1 & 0 \\
\hline Alanine aminotransferase $(7-45 \mathrm{U} / \mathrm{L})$ & 48 & 35 & 50 & 14 & 17 & 21 & 14 & 16 & 15 & 15 & 16 & 13 & 10 & 13 & 12 \\
\hline Aspartate aminotransferase (13-45 U/L) & 32 & 48 & 28 & 23 & 25 & 26 & 37 & 42 & 40 & 34 & 32 & 30 & 30 & 29 & 27 \\
\hline Blood creatinine (69-106umol/L) & 26 & 27 & 26 & 28 & 34 & 31 & 17 & 16 & 19 & 24 & 26 & 19 & 25 & 22 & 19 \\
\hline \multicolumn{16}{|l|}{ Radiography } \\
\hline Inflammatory changes in the lungs & $x$ & $x$ & $x$ & $x$ & $x$ & $x$ & $x$ & $x$ & $x$ & $x$ & $x$ & $x$ & $x$ & $x$ & $x$ \\
\hline \multicolumn{16}{|l|}{ SARS-CoV-2 RT-PCR } \\
\hline Nasopharyngeal swab & $x$ & $x$ & $x$ & $x$ & $x$ & $x$ & $x$ & $x$ & $x$ & $x$ & $x$ & $x$ & $x$ & $x$ & $x$ \\
\hline
\end{tabular}

$\boldsymbol{X}$, without; data are n; COVID-19, coronavirus disease 2019; SARS-CoV-2, severe acute respiratory syndrome coronavirus 2

CoV-2 detoxification time in nasopharyngeal swab was 16 (SD 5.4) days. We found patients with nasopharyngeal swabs turned negative, but SARS-CoV-2 could still be detected in the feces swabs during the same period. We also found all patients underwent multiple lung radiation without significant changes. We traced treatments and primary manifestations to assess disease progression and outcome, and varieties of treatments were given such as bed rest, ensuring calorie intake, monitoring vital signs, interferon atomization inhalation, and bifidobacterium triple live bacteria powder. The mean time in hospital was 18 (SD 5.4) days. By Feb 26, 2020 , all patients were cured and quarantined for a further 2 weeks.

\section{Comprehensive Follow-Up After Discharge}

Follow-up was continuing every 2 days after discharging to 4 weeks (Table 2). We found that the gastrointestinal detoxification time was mean 24 (SD 4.9) days, and the younger pediatric patient had decreased the time of gastrointestinal detoxification $(p=0.037)$. We did not find respiratory and digestive symptoms, and no abnormalities in blood laboratory and radiographic in pediatric patients. We also did not find positive RT-PCR test results in recovering COVID-19 pediatric patients.

\section{Discussion}

Researchers had predicted that the $\mathrm{R} 0$ values of the epidemic were 6.74 [4], which suggested that the epidemic had a strong ability to spread from person to person. There were fewer cases of COVID-19 infection in children than in adults, and it was more common in children with asymptomatic infection and mild and common infection, and the clinical symptoms were usually mild [5]. Familial clustering was the main way for children to be infected with COVID-19 [6]. Early laboratory tests and radiation tests could be atypical, and fecal SARS-CoV-2 measurements suggested that children in the recovery period still had the risk of being infected by excretion of the virus through fecal-oral transmission [7]. This means that virus-containing feces might be spread further by polluting the environment. Therefore, asking in detail epidemiological history was very important. Many researchers had reported that varieties of cases of recovered COVID-19 pediatric patients had positive RT-PCR test again. This might be due to biological characteristics of SARS-CoV-2 (a recombinant viruses) and might also be related to the basic disease, weak immune function, glucocorticoid using, processing and detecting of patients, and some even related to SARS-CoV-2 mutations [8]. At present, because the understanding of COVID19 infection was limited to us, further research was needed to strengthen the early identification and early diagnosis of COVID19 infection in children, especially in children with NCP and critically ill children with NCP. 
Acknowledgments We would like to acknowledge all of our colleagues of the Ningbo Women and Children's Hospital.

Authors' Contributions HQ designed the study and did the literature search. JW and HX were responsible for disease diagnosis and treatment and data collection. QS collected and analyzed the data. PR analyzed the data and wrote the report.

Funding This study was funded by Ningbo Clinical Research Center for Children's Health and Diseases, Project of Ningbo Reproductive Medicine Center (PPXK2018-06).

\section{Compliance with Ethical Standards}

Ethical Approval The study was approved by the Institutional Helsinki Committee, which waived the requirement to obtain written consent from the parents of studied patients.

Informed consent Informed consent was obtained from the patient's parents for publication of this report.

\section{References}

1. Lai CC, Shih TP, Ko WC, Tang HJ, Hsueh PR. Severe acute respiratory syndrome coronavirus 2 (SARS-CoV-2) and coronavirus disease-2019 (COVID-19): the epidemic and the challenges. Int J Antimicrob Agents. 2020;55:105924.
2. Bogoch II, Watts A, Thomas-Bachli A, Huber C, Kraemer MUG, Khan K. Potential for global spread of a novel coronavirus from China. J Travel Med. 2020;27:taaa011.

3. National Health and Health Commission of the People's Republic of China. Diagnosis and treatment guidelines for 2019 novel coronavirus pneumonia (draft version 7). (In Chinese). Available at http://www.nhcgoven/yzygj/ s7653p/202003/46c9294a7dfe4cef80dc7f5912eb1989shtml. Accessed March 4, 2020.

4. Tang B, Wang X, Li Q, Bragazzi NL, Tang S, Xiao Y, et al. Estimation of the transmission risk of the 2019-nCoV and its implication for public health interventions. J Clin Med. 2020;9:462.

5. Qiu H, Wu J, Hong L, Luo Y, Song Q, Chen D. Clinical and epidemiological features of 36 children with coronavirus disease 2019 (COVID-19) in Zhejiang, China: an observational cohort study. Lancet Infect Dis. 2020;20:689-96.

6. Chan JF, Yuan S, Kok KH, To KK, Chu H, Yang J, et al. A familial cluster of pneumonia associated with the 2019 novel coronavirus indicating person-to-person transmission: a study of a family cluster. Lancet. 2020;395:514-23.

7. Ling Y, Xu SB, Lin YX, Tian D, Zhu ZQ, Dai FH, et al. Persistence and clearance of viral RNA in 2019 novel coronavirus disease rehabilitation patients. Chin Med J (Engl). 2020;133:1039-43.

8. Zhou L, Liu K, Liu HG. Cause analysis and treatment strategies of "recurrence" with novel coronavirus pneumonia (covid-19) patients after discharge from hospital. Zhonghua Jie $\mathrm{He} \mathrm{He} \mathrm{Hu} \mathrm{Xi} \mathrm{Za}$ Zhi. 2020;43:281-4.

Publisher's Note Springer Nature remains neutral with regard to jurisdictional claims in published maps and institutional affiliations. 